\title{
Effect of coconut products, mesquite flour and stevia on the thermal and quality properties of dark chocolate
}

\author{
Zhivka Goranova ${ }^{1}$, Iordanka Alexieva ${ }^{2}$, Todorka Petrova ${ }^{1}$ \\ 1 - Institute of Food Preservation and Quality, Plovdiv, Agricultural Academy, Bulgaria \\ 2 - University of Food Technologies, Plovdiv, Bulgaria
}

Keywords:

Chocolate

Coconut

Mesquite

Stevia

Sweetener

Melting

Article history:

Received 12.03.2021

Received in revised

form 28.10.2021

Accepted 30.12.2021

\section{Corresponding}

author:

Zhivka Goranova

E-mail:

jivka_goranova@ abv.bg

DOI: $10.24263 / 2304-$

974X-2021-10-4-11

\section{Abstract}

Introduction. The present study aimed to investigate the effect of coconut products and mesquite flour on the thermal properties of dark chocolate with stevia.

Materials and methods. Cocoa butter, cocoa mass, stevia, coconut flour, mesquite powder, and coconut butter are used for the preparation of dark chocolate. Chocolate samples were prepared according to a classic technology. The determination of the energy value of the dark chocolate samples was performed through AOAC procedures. A differential scanning calorimeter was used for the determination of the melting points of the chocolate samples.

Results and discussion. An increase in the mass concentration of functional ingredients leads to an increase in the proteins, fats and a decrease in the carbohydrate content and lipid content. Lower concentrations of carbohydrates were identified in chocolate $1(38.11 \%)$ and chocolate $2(45.50 \%)$. From a statistical point of view $(p<0.05)$ it can be stated that there are notable differences between the concentration of carbohydrates in chocolate with stevia $0.01 \%$ and that of chocolate with stevia $0.03 \%$. These differences can be explained by the higher carbohydrate content of coconut flour.

Sweetener type and functional ingredients did not change the melting properties of the dark chocolate samples significantly $(\mathrm{p}>0.05)$. However, low melting temperatures around $27-35{ }^{\circ} \mathrm{C}$ implied that thus low-melting polymorphic forms occurred during the production of the samples. For stevia including dark chocolates, onset temperature $\left(\mathrm{T}_{\text {onset }}\right)$, peak temperature $\left(\mathrm{T}_{\text {peak }}\right)$ and end temperature $\left(\mathrm{T}_{\text {end }}\right)$ values were found between $25.01-28.57$ ${ }^{\circ} \mathrm{C}, 33.95-34.64{ }^{\circ} \mathrm{C}$, and 38.69-38.01 ${ }^{\circ} \mathrm{C}$. Concerning the $\Delta \mathrm{H}$ parameter, it varied from 32.60 to $33.06 \mathrm{~J} / \mathrm{g}$.

Samples with functional ingredients have significantly higher values for the antioxidant capacity indicator $97.21 \mu \mathrm{mol} \mathrm{TE} / \mathrm{g} \mathrm{d} . \mathrm{m}$. $-112.62 \mu \mathrm{mol} \mathrm{TE} / \mathrm{g}$ d.m.

Conclusion. Results of melting profile, and nutritional and antioxidant properties showed that the quality attributes of the chocolates with stevia were substantially affected by the ratio of the functional ingredients (mesquite flour and coconut products). 


\section{Introduction}

Chocolate and cocoa are produced from cacao beans, the seed of Theobroma cacao, and contain fats (the dry weight of whole cacao beans is composed of $50-57 \%$ lipid, often called cocoa butter) (Hannum et al., 2000). This cocoa butter, predominantly found in dark chocolate, is composed on average of $33 \%$ of oleic acid, $25 \%$ of palmitic acid, and $33 \%$ of stearic acid (Latif, 2013), the latter two are saturated fatty acid. Cocoa products are also very rich in plant phytochemicals, especially flavonoids, which are now objects of increased scientific attention due to their potential health benefits (Almoosawi et at., 2010; WangPolagruto et at., 2006).

Cocoa butter crystallizes in different forms as a function of processing condition, time and temperature of storage (Afoakwa et al., 2009). Phase transitions in cocoa butter polymorphs from less to more stable are irreversible and dependent on temperature and time. Polymorphism about solid continuous phases of cocoa butter has a large impact on chocolate quality, dictating their structural properties (Schenk et al., 2004). Structural factors such as microstructural elements and microstructure characteristics can provide quantitative information about the mechanical properties of the network, and therefore information about the sensory hardness of the network (Narine et al., 1999). Polymorphic changes can be observed as an overall contraction of chocolate, appearance, or undesirable fat bloom formation dependent on relative stabilities of crystal forms and temperature. Due to its thermal stability, it can be used in the production of chocolate (Mitchell et al., 2006).

Mesquite (Prosopis spp) pods having a high protein content in addition to the sucrose content offers a wide potential for the development of new functional products (Sandoval et al., 2018). The nutritional content of the powders reveals important properties for the mesquite flours. Flours have a high content of sugars and fiber, and an important content in protein (Sandoval et al., 2018). Flours are highly hygroscopic, and this fact can be explained by the content of sugar (Sandoval et al., 2018).

Chocolate is primarily composed of its natural fat, i.e., cocoa butter, with a total solid content of $65-75 \%$. In chocolate, the continuous phase provides a network structure that maintains the spatial position of the dispersed phase, determining its microstructure, texture, crystallization, and rheological properties, and conferring chocolate its characteristic flavor (Ramlah, 2016). There is no information relating antioxidant, sensory, and melting properties in chocolate products with stevia and functional ingredients. A priority area of expansion of the chocolate assortment is the development of enriched products with targeted functional properties while preserving traditional consumer characteristics. This can be achieved by reducing or replacing the amount of sugar and enrichment with functional ingredients. This is achieved through plant sources rich in fiber (mesquite flour and coconut flour), proteins (mesquite), and natural sugar substitutes (stevia and mesquite flour). In the literature, there is no data on the use of mesquite flour and coconut flour as functional components in the development of chocolate.

According to (Pantzaris et al., 2002), coconut oil is a desirable oil for confectionery formulations and has been applied in confectionery products like non-dairy/imitation dairy products, coffee whiteners, and biscuit-filler creams. In the production of chocolate, coconut oil was applied as a cocoa butter substitute to replace cocoa butter at a certain amount. Indarti et al. (2013) had observed that chocolate containing cocoa butter substitute from virgin coconut oil had a glossy appearance compared to chocolate without cocoa butter substitute. There were several research focused on using cocoa butter substitutes in chocolate from palm kernel oil (Sonwai et al., 2006; Wang et al., 2010). However, to the best of our knowledge, there is no attempt to use coconut oil as a cocoa butter substitute in chocolate. The use of 
coconut oil may affect the physicochemical properties of chocolate, improve the appearance and increase the stability against melting.

This research aims to find out the effect of functional ingredients namely mesquite flour and coconut products (flour and oil) on the sensory, physicochemical, thermal properties and the antioxidant content of chocolate using stevia as sweetener stevia.

\section{Materials and methods}

\section{Raw materials}

The raw materials were bought from the local market and the online market depends upon the availability. The required raw materials were as follows: cocoa mass, mesquite flour, cocoa butter, stevia, coconut flour, and coconut oil.

The study was conducted to develop and assess the nutritional value and melting properties of chocolates with functional ingredients. Two types of chocolates were prepared depending on the varying amount of stevia, coconut flour, and oil.

\section{Preparation of chocolate samples}

\section{Samples}

- Chocolate 1: cocoa mass $-60 \%$; cocoa butter $-20 \%$; stevia $-0.01 \%$; coconut flour $3 \%$; mesquite flour $-10 \%$; coconut oil $-6.99 \%$.

- Chocolate 2: cocoa mass $-60 \%$; cocoa butter - $15 \%$; stevia $-0.03 \%$; coconut flour $5 \%$; mesquite flour $-10 \%$; coconut oil $-9.97 \%$.

- Chocolate 3: cocoa mass - 60\%; cocoa butter - $13 \%$; stevia $-0.04 \%$; coconut flour $5 \%$; mesquite flour $-10 \%$; coconut oil $-11.96 \%$.

- Chocolate 4: cocoa mass $-60 \%$; cocoa butter $-10 \%$; stevia $-0.05 \%$; coconut flour $5 \%$; mesquite flour $-10 \%$; coconut oil $-14.95 \%$.

Chocolate was prepared using cocoa butter, coconut oil which were heated at a temperature of $40{ }^{\circ} \mathrm{C}$ in a double boiling setup. After the heating up of butter, the sieved powder of mesquite flour, coconut flour, and stevia were added and that was continuously stirred and mixed till the added ingredients were blended to form a brown smooth paste. The chocolate is cooled down to room temperature and further molded into the chocolate tray for stability, and the chocolate is cooled in the refrigerator.

\section{Sensory evaluation}

For the sensory evaluation, 4 chocolate samples were selected of possible sensory differences among the samples (Table 1).

For this reason, the chocolate samples were randomly selected and differed in ingredients. Samples were stored at a constant temperature of $20^{\circ} \mathrm{C}$. Chocolate samples were presented in odorless transparent cups, containing a small amount of chocolate (around $10 \mathrm{~g}$ ), foreseen with a random 3-digit code. Descriptive sensory profiling, according to the generic descriptive analysis (Lawless et al., 2010), was used to evaluate the selected chocolate samples. This panel consisted of 10 assessors (aged between 23 and 55 years old). 
The descriptive analysis was carried out at the sensory facilities of IFPQ-Plovdiv. Panelists were seated in individual booths and evaluated each sample. The assessors scored the samples using a 9-point scale ( $1=$ low intensity $-9=$ high intensity $)$.

Table 1

\section{Sensory indicators of chocolates}

\begin{tabular}{|c|c|c|c|c|c|}
\hline \multirow{2}{*}{ 弟 } & \multicolumn{5}{|c|}{ Characteristics } \\
\hline & 9 & $7-8$ & $5-6$ & $3-4$ & $1-2$ \\
\hline 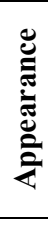 & $\begin{array}{l}\text { The surface is } \\
\text { shiny and } \\
\text { smooth }\end{array}$ & $\begin{array}{l}\text { The surface is } \\
\text { shiny, with a } \\
\text { little scratch }\end{array}$ & $\begin{array}{c}\text { The surface is } \\
\text { shiny, with a } \\
\text { small number } \\
\text { of bubbles }\end{array}$ & $\begin{array}{l}\text { The surface is } \\
\text { matte, the } \\
\text { presence of } \\
\text { pieces, crumbs, } \\
\text { bubbles }\end{array}$ & $\begin{array}{l}\text { The surface is } \\
\text { matte, the } \\
\text { presence of } \\
\text { bruises, } \\
\text { scratches, } \\
\text { crumbs }\end{array}$ \\
\hline : & $\begin{array}{l}\text { Hardness, } \\
\text { melting in the } \\
\text { mouth }\end{array}$ & $\begin{array}{l}\text { Hardness, } \\
\text { melting in } \\
\text { fingers }\end{array}$ & Stickiness & Breaking, snap & Creaminess \\
\hline 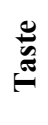 & $\begin{array}{c}\text { Sweet, with a } \\
\text { pleasant } \\
\text { bitterness }\end{array}$ & $\begin{array}{l}\text { Sweet, with } \\
\text { bitterness }\end{array}$ & Sweet & $\begin{array}{l}\text { Uncharacteristi } \\
\text { c, earthy }\end{array}$ & Aftertaste bitter \\
\hline 爮 & $\begin{array}{l}\text { The expressive } \\
\text { aroma of fruits, } \\
\text { cocoa, coconut, } \\
\text { nuts, caramel }\end{array}$ & $\begin{array}{l}\text { Pleasant aroma } \\
\text { of fruits, cocoa, } \\
\text { coconut, nuts, } \\
\text { caramel }\end{array}$ & Light aroma & Lack of aroma & $\begin{array}{l}\text { Specific aroma, } \\
\text { uncharacteristic } \\
\text { of chocolate }\end{array}$ \\
\hline
\end{tabular}

\section{Determination of moisture content}

The moisture was determined by the method described by AOAC. Determination of moisture content was done by the hot air oven method.

\section{Nutritional Value}

The proximate composition (moisture, proteins, fat, carbohydrates, and fiber) of chocolates was determined using AOAC procedures (AOAC, 1990). The protein content (N $\times 6.25)$ of the samples was estimated by the macro-Kjeldahl method; the fat content was determined by extraction using a Soxhlet apparatus. Total carbohydrates were calculated by difference. The energy was calculated according to the following equation: Energy $(\mathrm{kcal})=$ $4 \times(\mathrm{g}$ protein $+\mathrm{g}$ carbohydrate $)+9 \times(\mathrm{g}$ fat $)$. 


\section{Antioxidant activity assays (ABTS)}

The antioxidants of chocolates were determined by the spectrophotometric ABTS method according to procedures described in our previous article with some minor modifications (Szydłowska-Czerniak et al., 2014). The resulting absorbance of each obtained solution was measured in five repetitions using a spectrophotometer in a $1-\mathrm{cm}$ glass cell. The results were expressed as $\mu$ mol Trolox equivalents (TE) per $1 \mathrm{~g}$ of sample.

\section{Melting properties of the samples}

The melting properties of chocolate samples were determined using a differential scanning calorimeter (Perkin Elmer FC100 ped2 27603). $5 \mathrm{mg}$ of each sample was placed into a pan, which was sealed with lids using a sample press. The corresponding parameters representing melting profile of the samples, onset temperature ( $\mathrm{T}_{\text {onset }}$ where melting of the samples started), peak temperature ( $\mathrm{T}_{\text {peak }}$ where the highest rate of the melting was observed), end temperature ( $T_{\text {end }}$ where the samples melted completely), and $\Delta \mathrm{H}$ (energy required for complete melting of the samples) were calculated from the thermograms obtained after heating the pans from 0 to $60^{\circ} \mathrm{C}$ at $10^{\circ} \mathrm{C} / \mathrm{min}$ heating rate performed by $\mathrm{N}_{2}$ stream (Gloria et al., 2001).

\section{Data analysis}

All the data were statistically analyzed for variance (ANOVA) using Excel 10. The comparisons for means were done using Duncan's Multiple Range Tests. Duncan's new multiple range tests, provide significance levels for the difference between any pair of means, regardless of whether a significant $\mathrm{F}$ resulted from an initial analysis of variance. Principal component analysis using the correlation matrix was conducted using ANOVA to visualize the relationships between the chocolate samples and the sensory attributes for the different types of chocolate (Naes et al., 2010).

\section{Results and discussion}

A major difficulty in the production of chocolate with stevia, which completely replaces sugar, is the appearance of a specific bitterness, the elimination of which is a major task in the development of chocolate with natural sugar substitutes. To eliminate bitterness, functional components such as mesquite flour, coconut flour, and coconut oil are added. An optimal quantitative ratio of all ingredients contained in chocolate is selected. The compositions of chocolate were selected after preliminary sensory evaluations. The differences in the composition of the chocolate samples were in the amount of stevia and coconut oil. The selected two variants of chocolates were the best sensory characteristics and were included in subsequent analyzes regarding their quality.

\section{Sensory evaluation}

The trained panel indicated that no significant difference was present in the appearance of the four dark chocolate. The cocoa aroma was dominating the aroma of the dark chocolate although hints of coffee, tobacco, and fruit were perceived. Further, the evaluations of the trained panel indicated that significant differences were found in the texture of the four chocolates, chocolate samples 3 and 4 are melting behavior. 


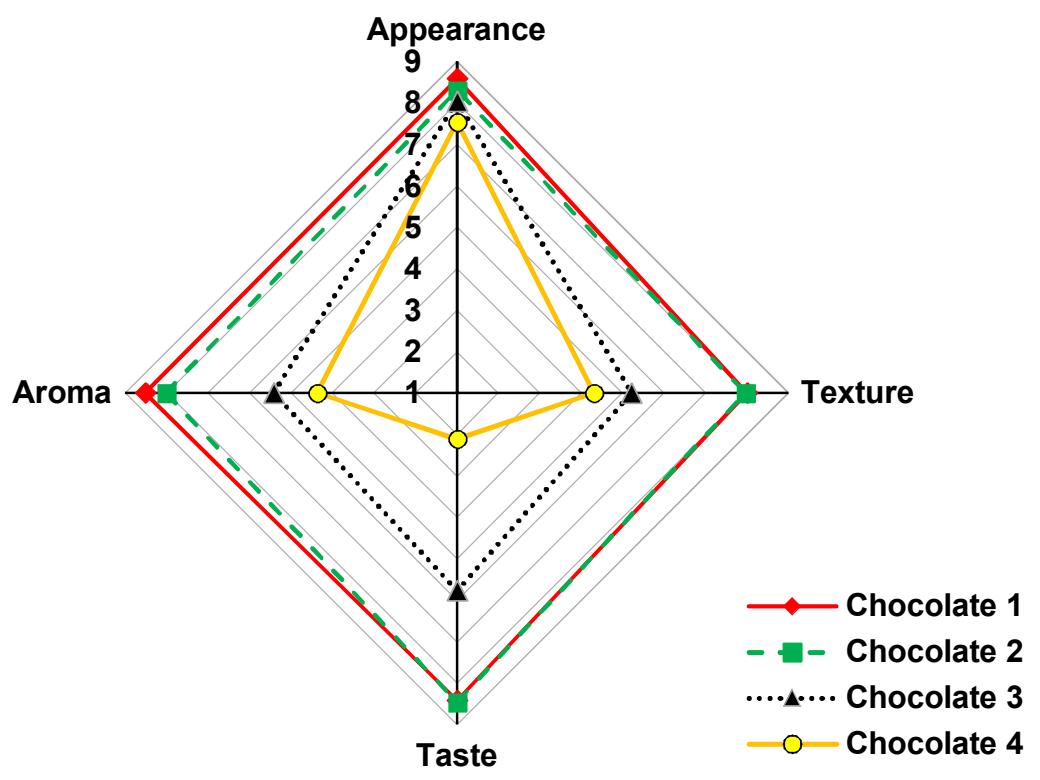

Figure 1. Sensory evaluation

The differences between the samples were found in the taste of the chocolate. The bitter taste was found to be most present in dark chocolate 3 and 4 . Chocolate 4 was evaluated as the most bitter chocolate. No significant difference was found between chocolate 1 and 2 regarding the bitter taste. Other significant differences were found for fruit and cocoa flavor. The fruity flavor of chocolate 2 was higher than that of other chocolates. Finally, the aftertaste after swallowing the samples was higher for chocolate 4.

Standardized plots using the correlation matrix are commonly used in sensory analysis to display differences between attributes as well as between samples. Figure 2 display the positioning and association between the chocolate attributes. The chocolate 1 larger differences are present for texture than for aroma and flavor.

Figure 2 shows that the three chocolate are closely related in terms of aroma. This suggests that the difference between the four types of chocolate is larger when looking at the aroma of the chocolate. This is also because not all ingredients were used in the equal qua of the different chocolate. The chocolate samples 1 and 4 are further from each other which indicates that these are more different from each other in aroma than the other two types of chocolate. The bitter taste and to a lesser extent sour taste are related to dark chocolates 3 and 4. Coffee, tobacco, earth and fruity flavor are also related to dark chocolate.

These plots can also demonstrate whether correlations exist between an aroma and flavor attribute that has been analyzed by the nose and by mouth (Naes et al., 2010). Most of these attributes such as caramel, nuts, cocoa, tobacco, fruity, honey, each were closely associated with one another, indicating that these notes were perceived similarly on the nose as well as the palate with the same intensity. Future research could combine this analysis from a trained panel with instrumental aroma or flavor analysis. This was not included in this research due to limited time. 


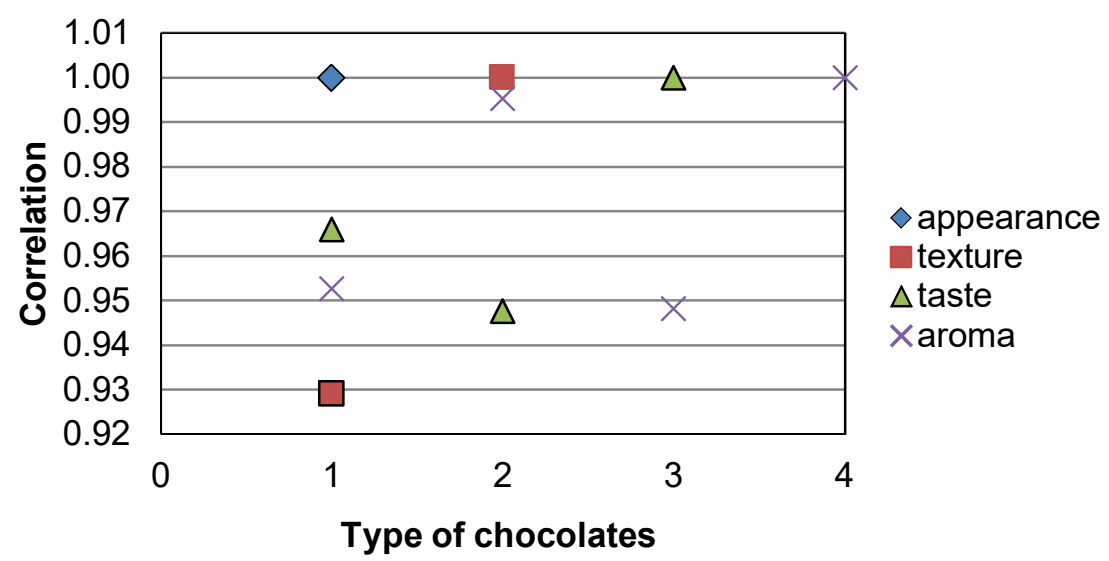

Figure 2. Correlation analysis of the significant attributes for the four types of chocolate

\section{Nutritional characteristics}

The nutritional composition of chocolate is mainly determined by the nature and nutritional value of the ingredients from which it is obtained and has different values, depending on the type of chocolate, how to obtain it (Barišic et al., 2019). Table 2 presents the fat, protein, carbohydrate, moisture content of sucrose-free chocolate.

Table 2

Nutritional properties of dark chocolate $\mathrm{g} / \mathbf{1 0 0 \mathrm { g }}$

\begin{tabular}{|l|c|c|c|c|c|}
\hline $\begin{array}{l}\text { Types of } \\
\text { chocolate }\end{array}$ & $\begin{array}{c}\text { Fat } \\
\mathbf{( \% )}\end{array}$ & $\begin{array}{c}\text { Protein } \\
(\mathbf{\%})\end{array}$ & $\begin{array}{c}\text { Carbohydrate } \\
(\mathbf{\%})\end{array}$ & $\begin{array}{c}\text { Fiber } \\
\mathbf{( \% )}\end{array}$ & $\begin{array}{c}\text { Moisture } \\
(\mathbf{\%})\end{array}$ \\
\hline Chocolate 1 & 23.25 & 7.20 & 38.11 & 7.34 & 7.34 \\
\hline Chocolate 2 & 21.03 & 8.90 & 45.50 & 8.61 & 8.12 \\
\hline
\end{tabular}

It can be seen from Table 2 that the fat content in dark chocolate 1 has a higher value than chocolate 2. This difference is because dark chocolate uses a higher proportion of cocoa butter. In addition, the effect of functional ingredients can determine the fat content in chocolate. The results show that the protein content in chocolate 2 is higher than in dark chocolate 1 . This variance is probably due to stevia, which does not affect the protein content in chocolate. Lin et al. (2010) used erythritol as a substitute for sucrose in making Danish cookies which is not much different from using sucrose. Analyzing the proximate composition of two types of chocolate, Latif et al. (2013) obtained the following values: per $100 \mathrm{~g}$ of the dark chocolate: $6.6 \mathrm{~g}$ of protein, $33.6 \mathrm{~g}$ of lipids, $49.7 \mathrm{~g}$ of carbohydrates, 50.5 of sugar; the energy value was $515 \mathrm{kcal}$ and per $100 \mathrm{~g}$ of the milk chocolate: $7.3 \mathrm{~g}$ of protein, $36.3 \mathrm{~g}$ of lipids, $50.7 \mathrm{~g}$ of of carbohyFdrates, $49.7 \mathrm{~g}$ of sugar, the energy value was $545 \mathrm{kcal}$.

Albak and Tekin (2014) made some assortments of functional chocolate with spices (cinnamon, aniseed, and ginger) and lemon peel powder. Proximate composition of of these chocolates is the following: 0.52 (dark chocolate) $-0.96 \%$ (aniseed chocolate) for moisture; 30.70 (in cinnamon chocolate) $-34.71 \%$ (in ginger chocolate) for fats; 8.42 (in dark 
chocolate) $-9.47 \%$ (in aniseed chocolate), for protein; 1.73 (in dark chocolate) $-2.15 \%$ (in cinnamon chocolate), for ash; 52.49 (in dark chocolate) - 57.80 (in cinnamon chocolate), for carbohydrate.

Stevia is also good for preventing moisture adsorption on chocolate. If the stevia concentration increases, the moisture absorption will be less, so the water content will decrease. According to research by Shourideh et al. (2012), in milk chocolate with an inulin concentration below $50 \%$, the water content of the product did not increase. In contrast, if the concentration increased, the water content would increase.

The higher water content is caused by stevia, which is hygroscopic and can bind free water in the material. The higher the addition of sweetener in a food, the more free water is bound (Afoakwa et al., 2007). When there is heating in the manufacture of sucrose-free dark chocolate, the water is evaporated slightly. This is because when measuring the moisture content in chocolate, it will produce more water when compared to sucrose.

Statistically significant differences $(\mathrm{p}<0.05)$ were determined in the two chocolates with added new ingredients. Comparing the average value of the protein content determined in chocolate $1(7.20 \%)$ with that determined in chocolate $2(8.90 \%)$, it is observed that there are statistically significant differences $(\mathrm{p}<0.05)$. These differences can be explained by the amount of protein contained in the mesquite addition. As can be seen from the data presented in Table 2, the highest carbohydrate content was identified in chocolate $2(45.50 \%)$. Lower content of carbohydrates was identified in chocolate $1(38.11 \%)$. From a statistical point of view $(\mathrm{p}<0.05)$ it can be stated that there are notable differences between the concentration of carbohydrates in chocolate 1 and that of chocolate 2 . These differences can be explained by the higher carbohydrate content of coconut flour.

\section{Melting properties}

DSC evaluates the structure density, homogeneity, crystal network, and tempering of dark chocolate. The melting characteristic investigated by DSC is an important quality parameter relating to flavor release and oral epithelial sensations. Melting properties $\left(\mathrm{T}_{\text {onset }}\right.$, $\mathrm{T}_{\text {peak }}, \mathrm{T}_{\text {end }}$ and $\left.\Delta \mathrm{H}\right)$ of the sugar-free chocolates with functional ingredients are presented in Table 3 .

Table 3

Melting profile of dark chocolates

\begin{tabular}{|l|c|c|c|c|}
\hline \multirow{2}{*}{$\begin{array}{c}\text { Type of } \\
\text { chocolate }\end{array}$} & \multicolumn{4}{|c|}{ Melting Profile } \\
\cline { 2 - 5 } & $\mathbf{T}_{\text {onset }}\left({ }^{\circ} \mathbf{C}\right)$ & $\mathbf{T}_{\text {peak }}\left({ }^{\circ} \mathbf{C}\right)$ & $\mathbf{T}_{\text {endset }}\left({ }^{\circ} \mathbf{C}\right)$ & $\Delta \mathbf{H ~ ( J / g )}$ \\
\hline Chocolate 1 & $25.01 \pm 0.03^{\mathrm{a}}$ & $33.95 \pm 0.05^{\mathrm{a}}$ & $38.69 \pm 0.07^{\mathrm{a}}$ & $32.60 \pm 0.05^{\mathrm{a}}$ \\
\hline Chocolate 2 & $28.57 \pm 0.01^{\mathrm{b}}$ & $34.64 \pm 0.05^{\mathrm{b}}$ & $38.01 \pm 0.04^{\mathrm{a}}$ & $33.06 \pm 0.09^{\mathrm{b}}$ \\
\hline
\end{tabular}

All values are shown as mean \pm standard deviations $(n=3)$.

Different letters $a, b$, indicate significant differences $(\mathrm{p}<0.05)$ in the melting profile of different types of dark chocolate.

For stevia including dark chocolates, Tonset, Tpeak and Tend values were found between 25.01-28.57 ${ }^{\circ} \mathrm{C}, 33.95-34.64{ }^{\circ} \mathrm{C}$, and 38.69-38.01 ${ }^{\circ} \mathrm{C}$. Concerning the $\Delta \mathrm{H}$ parameter, it varied from 32.60 to $33.06 \mathrm{~J} / \mathrm{g}$. Neither sweetener type nor seeding did not change the melting properties of the dark chocolate samples significantly $(\mathrm{p}>0.05)$. However, low melting temperatures around $27-35{ }^{\circ} \mathrm{C}$ implied that thus low-melting polymorphic forms occurred during the production of the samples (Afoakwa et al., 2007). The thermal behavior of chocolate, with additives in question, was studied in DSC to see 
their effect on the melting point characteristics. It is seen that the fat melting profile corresponding to each additive is different. It is known that the peak temperature for melting is the average melting point of chocolate and the onset of melt indicates the time when the fat just starts to melt. The melting properties of chocolate are important because of its contribution to the taste and sensation in the mouth. Marangoni and McGauley (2003) stated that the structure of fat in a food product is an important property that strongly influences its perceived mechanical and melting properties. These results show that functional ingredients affected the melting point of the dark chocolate within the proportion they added. Especially coconut flour and oil were observed to be more effective in increasing the melting point in comparison with cocoa butter probably due to its higher fiber content.

Thermal behaviors and the ratio of sugar/fat-melting enthalpies in chocolates differing in temper regime were studied using DSC to provide information on differences in structure.

The DSC data showed differences in fat melting profile, resulting from the widened peak width in the under-tempered (bloomed) sample; but no differences were noted in the sugar melting profiles, suggesting that blooming of under-tempered dark chocolate is associated with structural transformations in the fat component alone while the crystalline network of the sugar remains unchanged.

Chocolate refers to products with high antioxidant activity. The antioxidant capacity of the newly developed chocolate samples has been determined and compared to that of the control (Table 4).

\section{Total content of antioxidants in the chocolates}

Table 4

\begin{tabular}{|c|c|}
\hline Type of chocolate & TE $_{\text {ABTs, } \boldsymbol{\mu m o l ~ T E} / \mathbf{g} \text { d.m. }}$ \\
\hline Sample 1 & $97.21 \pm 0.03$ \\
\hline Sample 2 & $112.62 \pm 0.06$ \\
\hline
\end{tabular}

It is known that antioxidants interrupt radical-chain oxidation processes in the human body caused by free radicals as a result of exposure to factors of exogenous origin (chemical environmental pollutants, ionizing radiation of radionuclides) and as a result of biochemical metabolic reactions in the cells of the body (Kozlova et al., 2014). From the data obtained in Table 4, samples with functional ingredients can be seen to have significantly higher values for the antioxidant capacity indicator $-97.21 \mu \mathrm{mol} \mathrm{TE} / \mathrm{g} \mathrm{d} . \mathrm{m}$. and $112.62 \mu \mathrm{mol} \mathrm{TE} / \mathrm{g} \mathrm{d}$.m. The effect of rosemary and grape seed particles on crystallization, rheological, shelf life, and antioxidant activities of chocolate was studied (Ozgen et al., 2010). They found that there was no effect of these additives on the crystallization and rheological properties of chocolate while they increased its shelf life and antioxidant capacity. In a Ph.D. thesis by Çağındı (Cağındı et al., 2009) some physical, chemical, and sensory properties of white and dark chocolates with enriched milk, sunflower seed, flaxseed, oat, and dried damson plum particle was investigated. It was concluded that these ingredients increased the nutritional value of chocolate and changed some physical, chemical, and sensory properties during the storage period.

In a study on the identification of antioxidants compounds from dark chocolate with the addition of some spices and herbs, Mira Suprayatmi et al. (2017a) found that the addition of ground ginger, cinnamon powder, red chili powder, powdered mint leaf, powdered green tea leaf, and powdered linden leaf, increases the antioxidant content of chocolate. Moreover, in another study, Mira Suprayatmi et al. obtained three types of dark chocolate with the addition 
of powdered mint leaves, powdered green tea leaves, and powdered lime leaves, each at $4 \%$ (w/w) (Suprayatmi et al., 2017b).

The study authors found that the chocolate products with the addition of powdered mint leaves, powdered green tea leaves and powdered lime leaf were experiencing an increase in the number of types of antioxidants.

\section{Conclusion}

1. The combination of stevia and mesquite flour and coconut products as a bulking agent on dark chocolate can improve the protein and fat content. Addition of stevia decreases the content of carbohydrates.

2. An increase in the mass concentration of functional ingredients, leads to an increase in the contents of proteins, fats and a decrease in the carbohydrate content.

3. Results of the melting profile showed that the quality attributes of the chocolates were not substantially affected by functional ingredients level, which is important for the consumer acceptability of the product. Considering the purpose of improving the nutritional and technological quality of dark chocolate, the use of stevia and functional ingredients is highly recommended.

\section{Reference}

Afoakwa E. O., Paterson A., Fowler M. (2007), Factors Influencing Rheological and Textural Qualities in Chocolate - A Review, Trends in Food Science and Technology, 18, pp. 290 298.

Afoakwa E., Paterson A., Fowler M., Vieira, J. (2009), Influence of tempering and fat crystallization behaviours on microstructural and melting properties in dark chocolate systems, Food Research International, 42(1), pp. 200-209.

Albak F., Tekin A.R. (2014), Development of functional Chocolate with spices and lemon peel powder by using response surface method, Akademik Glda, 12(2), pp. 19-25.

Almoosawi S., Fyfe L., Ho C., Al-Dujaili E. (2010), The effect of polyphenol-rich dark chocolate on fasting capillary blood glucose, total cholesterol, blood pressure and glucocorticoids in healthy overweight and obese subjects, British Journal of Nutrition, 103, pp. 842-850.

AOAC (1990), Official Methods of Analysis vol 2. 15 th edition Aspects of Official Analysis Chemistry, Inc. Arlington.

Barišic V., Kopjar M., Jozinovic A., Flanjak I., Ackar D., Milicevic B., Šubaric D., Jokic S., Babic J. (2019), The Chemistry behind Chocolate Production, Molecules, 24, pp. 3163-3176

Cağındı Ö. (2009), Investigation of some physical, chemical and sensory properties of sunflower seed, flax seed, oat and dried damson plum enriched milk, dark and white chocolates during shelf life. PhD Thesis, Ege University, İzmir, Turkey.

Gloria H., Sievert D. (2001), Changes in the physical state of sucrose during dark chocolate, processing, Journal of Agricultural Food Chemistry, 49, pp. 2433-2436.

Hannum S. M., Erdman Jr. J. W. (2000), Emerging health benefits from cocoa and chocolate, Journal of Medicinal Food, 3, pp. 73-75.

Indarti E., Arpi N., Widayat H. P., Anhar A. (2013), Appearance, texture and flavour improvement of chocolate bar by Virgin Cococnut Oil (VCO) as Cocoa Butter Substitute (CBS), In: Proceedings of the Annual International Conference, Syiah Kuala University-Life Sciences \& Engineering, Chapter 3(1). 
Kozlova T.S., Syngeeva E.V., Balchugova N.N. (2014), Study of the effect of germination duration and processing methods on the antioxidant properties of grain, Polzunov Altai State Technical University, Barnaul, pp. 442-444.

Lawless H.T., Heymann, H. (2010), Sensory Evaluation of Food: Principles and Practices (second edtion ed.), Springer, New York.

Latif R. (2013), Chocolate/cocoa and human health: a review, The Netherlands Journal of Medicine, 71, pp. 63-68.

Lin S. D., Lee C. C., Mau J. L., Lin L. Y., Chiou S. Y. (2010), Effect of erythritol on quality characteristics of reduced-calorie danish cookies, Journal of Food Quality, 33, pp. 14-26

Naes T., Brockhoff P. B., Tomic O. (2010), Statistics for Sensory and Consumer Science, John Wiley \& Sons, Ltd, Chichester, pp. 209-224.

Nur M., Suryatiani D. R., Dewi R. L., Sari A. B. T. (2021), The effect of bulking agent and type of chocolate on the physicochemical characteristics of sucrose-free chocolate using stevia as a sweetener, IOP Conference Series: Earth Environmental Science, 733, 012102.

Marangoni A. G., McGauley, S. E. (2003), Relationship between crystallizationbehavior and structure in cocoa butter, Crystal Growth \& Design, 3(1), pp. 95-108

Mitchell H., (2006), Sweetners and sugar alternatives in food technology, Blackwell publishing Ltd, Oxford.

Narine S.S., Marangoni, A.G. (1999), Relating structure of fat crystal networks to mechanical properties: A review, Food Research International, 32, pp. 227-248.

Ozgen O. (2010), The effects of rosemary (Rosmarinus officinalis) and grape seed (Vitis vinifera) on crystallization, rheological properties, shelf life and antioxidant activities of chocolate. PhD Thesis, İstanbul Technical University, İstanbul.

Pantzaris T.P., Basiron Y. (2002), The lauric (coconut and palm kernel) oils F.D. Gunstone (Ed.), Vegetable Oils in Food Technology: Composition, Properties and Uses, Blackwell Publishing, USA and Canada, pp. 157-202.

Ramlah S. (2016), Quality characteristics and taste of chocolate rich in polyphenols, Journal of Plantation Products Industry, 11, pp. 23-32.

Sandoval Torres S., Reyes López L., Méndez Lagunas L., Rodríguez Ramírez J., Barriada Bernal G. (2018), Physicochemical characterization of mesquite flours, 21st International Drying Symposium, Editorial Universitat Politècnica De València, pp. 989-996, DOI: 10.4995/ids2018.2018.7707

Schenk H., Pescha R. (2004), Understanding the structure of chocolate, Radiation Physics and Chemistry, 71, pp. 829-835.

Shourideh M., Taslimi A., Azizi M., Mohammadifar M. (2012), Effects of D-tagatose and inulin on some physicochemical, rheological and sensory properties of dark chocolate, International Journal of Bioscience, Biochemistry and Bioinformatics, 2, pp. 314.

Sonwai S., Rousseau, D. (2006), Structure evolution and bloom formation in tempered cocoa butter during long-term storage, Eur. J. Lipid Sci. Tech., 108(9), pp. 735-745

Suprayatmi M., Hutami R., Tiastadia I.P. (2017a), Identification of antioxidants on dark chocolate compound with addition of some spices and herbs, Short communication, DOI: 10.13140/RG.2.2.29430.40004

Suprayatmi M., Hutami R., Tiastadia I.P., Purnamasari D. (2017b), Profile of antioxidant in dark chocolate product that enriched with herbs, Proceedings of the International Food Research Conference, Selangor, Malaysia, 2017, Available at: https://www.researchgate.net/publication/350781474

Szydłowska-Czerniak A., Tułodziecka A. (2014), Antioxidant capacity of rapeseed extracts obtained by conventional and ultrasoundassisted extraction, Journal of the American Oil Chemists' Society, 91, pp. 2011-2019.

Tokede O., Gaziano J., Djoussé L. (2011), Effects of cocoa products/dark chocolate on serum lipids: a meta-analysis, European Journal of Clinical Nutrition, 65, pp. 879-886. 
Wang F., Liu, Y., Shan, L., Jin, Q., Meng, Z., Wang X. (2010), Effect of fat composition on texture and bloom of lauric compound chocolate, European Journal of Lipid Science and Technology, 112(11), pp. 1270-1276.

Wang-Polagruto J.F., Villablanca A.C., Polagruto J.A., Lee L., Holt R R., Schrader H.R. (2006), Chronic consumption of flavanol-rich cocoa improves endothelial function and decreases vascular cell adhesion molecule in hypercholesterolemic postmenopausal women, Journal of Cardiovascular Pharmacology, 47(Suppl 2), pp. S177-S186. 